\title{
Front Matter: Volume 8170
}

, "Front Matter: Volume 8170," Proc. SPIE 8170, Illumination Optics II, 817001 (13 October 2011); doi: 10.1117/12.913086

SPIE. Event: SPIE Optical Systems Design, 2011, Marseille, France 


\section{PROCEEDINGS OF SPIE}

\section{Illumination Optics II}

Tina E. Kidger

Stuart David

Editors

7-8 September 2011

Marseille, France

Sponsored by

SPIE

Coorganised by

POPsud - Optitec (France)

Cosponsored by

Communauté Urbaine Marseille Provence Métropole (France)

Ville de Marseille (France)

Cooperating Organisation

Schott AG (Germany)

Published by

SPIE 
The papers included in this volume were part of the technical conference cited on the cover and title page. Papers were selected and subject to review by the editors and conference program committee. Some conference presentations may not be available for publication. The papers published in these proceedings reflect the work and thoughts of the authors and are published herein as submitted. The publisher is not responsible for the validity of the information or for any outcomes resulting from reliance thereon.

Please use the following format to cite material from this book:

Author(s), "Title of Paper," in Illumination Optics II, edited by Tina E. Kidger, Stuart David, Proceedings of SPIE Vol. 8170 (SPIE, Bellingham, WA, 2011) Article CID Number.

ISSN 0277-786X

ISBN 9780819487964

Published by

SPIE

P.O. Box 10, Bellingham, Washington 98227-0010 USA

Telephone +1 3606763290 (Pacific Time) · Fax +1 3606471445

SPIE.org

Copyright () 2011, Society of Photo-Optical Instrumentation Engineers

Copying of material in this book for internal or personal use, or for the internal or personal use of specific clients, beyond the fair use provisions granted by the U.S. Copyright Law is authorized by SPIE subject to payment of copying fees. The Transactional Reporting Service base fee for this volume is $\$ 18.00$ per article (or portion thereof), which should be paid directly to the Copyright Clearance Center (CCC), 222 Rosewood Drive, Danvers, MA 01923. Payment may also be made electronically through CCC Online at copyright.com. Other copying for republication, resale, advertising or promotion, or any form of systematic or multiple reproduction of any material in this book is prohibited except with permission in writing from the publisher. The CCC fee code is 0277-786X/11/ \$18.00.

Printed in the United States of America.

Publication of record for individual papers is online in the SPIE Digital Library.

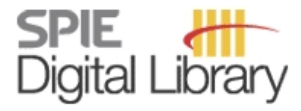

SPIEDigitalLibrary.org

Paper Numbering: Proceedings of SPIE follow an e-First publication model, with papers published first online and then in print and on CD-ROM. Papers are published as they are submitted and meet publication criteria. A unique, consistent, permanent citation identifier (CID) number is assigned to each article at the time of the first publication. Utilization of CIDs allows articles to be fully citable as soon as they are published online, and connects the same identifier to all online, print, and electronic versions of the publication. SPIE uses a six-digit CID article numbering system in which:

- The first four digits correspond to the SPIE volume number.

- The last two digits indicate publication order within the volume using a Base 36 numbering system employing both numerals and letters. These two-number sets start with 00, 01, 02, 03, 04 , $05,06,07,08,09,0 A, 0 B \ldots$. OZ, followed by 10-1Z, 20-2Z, etc.

The CID number appears on each page of the manuscript. The complete citation is used on the first page, and an abbreviated version on subsequent pages. Numbers in the index correspond to the last two digits of the six-digit CID number. 


\section{Contents}

vii Conference Committee
ix Introduction

\section{SESSION 1 DESIGN OF FREEFORM SURFACES}

817002 Boundary conditions for balancing light in tailoring freeform surfaces (Invited Paper) [8170-01]

H. Ries, OEC AG (Germany)

817003 Field method for dielectric concentrator design [8170-02]

A. García-Botella, Univ. Politécnica de Madrid (Spain); A. A. Fernández-Balbuena,

D. Vázquez, Univ. Complutense de Madrid (Spain)

817004 New iterative flux based in the design strategy for freeform surfaces generation for LED lighting technology [8170-03]

J. Arasa, E. Oteo, J. Fernandez-Dorado, Univ. Politècnica de Catalunya (Spain); P. Blanco,

C. Pizarro, SnellOptics (Spain); J. A. Diaz, Univ. de Granada (Spain)

817005 Spiral optical designs for nonimaging applications [8170-05]

P. Zamora, Univ. Politécnica de Madrid (Spain); P. Benítez, J. C. Miñano, Univ. Politécnica de Madrid (Spain) and Light Prescriptions Innovators, LLC (United States); J. Vilaplana, Light

Prescriptions Innovators, LLC (United States); M. Buljan, Univ. Politécnica Madrid (Spain)

817006 Tolerancing free-form optics for illumination [8170-32]

A. Timinger, J. Unterhinninghofen, S. Junginger, A. Hofmann, OEC AG (Germany)

\section{SESSION 2 FREEFORM APPLICATION}

$817007 \quad$ A review of beam shaping strategies for LED lighting [8170-06]

F. R. Fournier, Synopsys, Inc. (United States)

817008 Automotive headlamp concepts with low-beam and high-beam out of a single LED [8170-07]

P. Brick, T. Schmid, OSRAM Opto Semiconductors GmbH (Germany)

817009 Design of high-efficient freeform LED lens for road illumination [8170-09]

M. A. Moiseev, L. L. Doskolovich, N. L. Kazanskiy, Image Processing Systems Institute (Russian Federation) and Samara State Aerospace Univ. (Russian Federation)

$81700 \mathrm{~A}$ Optical design of adaptive automotive headlight system with digital micro mirror device [8170-10]

C.-M. Tsai, Kun Shan Univ. (Taiwan); Y.-C. Fang, National Kaohsiung First Univ. of Science and Technology (Taiwan) 
8170 OB Design of extreme anamorphic laser illumination systems [8170-11]

A. M. Herkommer, Univ. Stuttgart (Germany); H. Münz, Carl Zeiss Laser Optics GmbH

(Germany); R. Reichle, Univ. Stuttgart (Germany)

$81700 \mathrm{C}$ Near infrared laser illuminator for very long-range flash active imaging applications [8170-12]

Y. Lutz, N. Metzger, Institut Franco-Allemand de Recherches de Saint-Louis (France)

8170 OD A laser speckle reduction system [8170-13]

J. M. Cobb, P. Michaloski, Corning Advanced Optics (United States)

8170 OE Mask aligner process enhancement by spatial filtering [8170-15]

U. Vogler, A. Bich, R. Voelkel, SUSS MicroOptics SA (Switzerland); L. Stuerzebecher, U. Zeitner, Fraunhofer-Institut für Angewandte Optik und Feinmechanik (Germany); M. Hornung, SUSS

MicroTec Lithography GmbH (Germany)

\section{SESSION 4 LED COUPLING I}

8170 OF Optics detailed analysis of an improved collimation system for LED light sources [8170-16] M. González-Montes, D. Vázquez-Moliní, A. A. Fernandez-Balbuena, Univ. Complutense de Madrid (Spain); A. Garcia-Botella, Univ. Politécnica de Madrid (Spain);

E. Bernabeu-Martinez, Univ. Complutense de Madrid (Spain)

8170 OG Metal-less V-groove RXI collimator [8170-17]

D. Grabovičkić, Univ. Politécnica de Madrid (Spain); J. C. Miñano, P. Benítez, Univ. Politécnica de Madrid (Spain) and Light Prescriptions Innovators, LLC (United States); J. López, Univ. Politécnica de Madrid (Spain); J. Vilaplana, Light Prescriptions Innovators, LLC (United States); G. Biot, M. Buljan, Univ. Politécnica de Madrid (Spain)

$8170 \mathrm{OH} \quad$ LED collimation using high-index glass [8170-18]

R. Biertümpfel, S. Reichel, SCHOTT AG (Germany)

SESSION 5

\section{LED COUPLING II}

81700 ol Dielectric multilayer angular filters for coupling LEDs to thin light guides [8170-19]

C. Mu, Technische Univ. Delft (Netherlands); H. J. Cornelissen, Philips Research Nederland B.V. (Netherlands); F. Bociort, T. Liebig, Technische Univ. Delft (Netherlands)

8170 0J Employing the conventional edge-lighting technology into ultraviolet-range: a preliminary study by optical simulation [8170-20]

L. Ye, P. Belloni, K. Möller, Hochschule Furtwangen Univ. (Germany)

8170 OK A study of optical design of backlight module with external illuminance [8170-21] C.-T. Yen, National Formosa Univ. (Taiwan); Y.-C. Fang, National Kaohsiung First Univ. of Science and Technology (Taiwan) 
$8170 \mathrm{OL}$ Using the on-axis BSDF at a dielectric surface to model the BSDF at off-axis angles (Invited Paper) [8170-22]

W. J. Cassarly, Synopsys, Inc. (United States)

8170 OM Optics designs for an innovative LED lamp family system [8170-31]

H. Weiss, J. Muschaweck, S. Hadrath, OSRAM AG (Germany); S. Kudaev, PerkinElmer Elcos GmbH (Germany)

$81700 \mathrm{~N}$ What's in a ray set: moving towards a unified ray set format [8170-24]

J. Muschaweck, OSRAM AG (Germany)

8170 OP Laser dark-field illumination system modeling for semiconductor inspection applications [8170-27]

W. Zhou, D. Hart, R. Roy, Rudolph Technologies, Inc. (United States)

\section{POSTER SESSION}

$81700 Q \quad$ Methods for color mixing [8170-23]

S. Hadrath, OSRAM AG (Germany)

8170 OR Application of low-discrepancy sequences for evaluation of illumination optical systems [8170-28]

S. Yoshida, S. Horiuchi, Z. Ushiyama, K. Yoshidome, T. Yamada, M. Yamamoto, Tokyo Univ. of Science (Japan)

8170 OS Smooth light extraction in lighting optical fibre [8170-29]

A. A. Fernandez-Balbuena, D. Vazquez-Molini, Univ. Complutense de Madrid (Spain);

A. Garcia-Botella, Univ. Politécnica de Madrid (Spain); J. C. Martinez-Anton, E. Bernabeu, Univ. Complutense de Madrid (Spain)

8170 OT Lighting quality for aluminum and prismatic light guides [8170-30]

B. García-Fernández, D. Vázquez-Molini, A. Á. Fernández-Balbuena, Univ. Complutense de Madrid (Spain)

8170 OU Ultra-slim collimator with an inverse design [8170-33]

E. Aslanov, N. Petrov, A. Borodulin, G. Tananaev, LG Electronics Inc. (Russian Federation)

Author Index 
Downloaded From: https://www.spiedigitallibrary.org/conference-proceedings-of-spie on 26 Apr 2023

Terms of Use: https://www.spiedigitallibrary.org/terms-of-use 


\title{
Conference Committee
}

\author{
Symposium Chair
}

Michel Lequime, Institut FRESNEL and Ecole Centrale Marseille (France)

Symposium Cochairs

Andreas Tünnermann, Fraunhofer-Institut für Angewandte Optik und Feinmechanik (Germany)

David M. Williamson, West Malvern (United Kingdom) and Nikon

Research Corporation of America (United States)

Conference Chairs

Tina E. Kidger, Kidger Optics Associates (United Kingdom)

Stuart David, Optical Research Associates (United States)

Program Committee

Pablo Benitez, Universidad Politécnica de Madrid (Spain)

William J. Cassarly, Optical Research Associates (United States)

Joshua M. Cobb, Corning Tropel Corporation (United States)

Florian R. Fournier, Optical Research Associates (United States)

R. John Koshel, Photon Engineering LLC (United States)

Juan C. Miñano, Universidad Politécnica de Madrid (Spain)

Julius A. Muschaweck, OSRAM Opto Semiconductors GmbH (Germany)

Jannick P. Rolland, University of Rochester (United States)

Andreas L. Timinger, OEC AG (Germany)

Teus W. Tukker, Philips Lighting B.V. (Netherlands)

Session Chairs

1 Design of Freeform Surfaces

Florian R. Fournier, Synopsys, Inc. (United States)

2 Freeform Application

William J. Cassarly, Synopsys, Inc. (United States)

3 Laser and Projection

Joshua M. Cobb, Corning Tropel Corporation (United States)

$4 \quad$ LED Coupling I

Julius A. Muschaweck, OSRAM GmbH (Germany) 
5 LED Coupling ॥

Julius A. Muschaweck, OSRAM GmbH (Germany)

$6 \quad$ Optical Modeling

Stuart David, Synopsys, Inc. (United States) 


\section{Introduction}

Illumination Optics II, as is somewhat implied by the title, was the second European illumination optics conference managed by SPIE Europe; the first being held in Glasgow, Scotland, September 2008. These European illumination conferences evolved from creative conversations between Karin Burger, SPIE Europe and Tina Kidger, Kidger Optics Associates at SPIE's Optical Systems Design conference in Jena, Germany, 2005. As is evident, they have been a success from the start and continue to be a success today. Interest in illumination optics having been on the rise for over twenty years, the subject is now a major part of optical design activity with expectations of significant continued growth from here. The organizers are appreciative, pleased and thankful to all those who contribute to these meetings. Illumination Optics II drew authors from as far away as Taiwan and Russia, while including many local contributions from continental Europe and the UK.

Noticeable within Illumination Optics II was the heightened interest in Freeform optics technology with sessions on Freeform surfaces and Freeform applications drawing large audiences. Discussions of considerable interest and excitement occurred on the theory and application of Freeform technology. Given today's enhanced facility for optical analysis and fabrication, Freeform optics is seen to be extremely fertile ground for further research and development, and we expect it to be a major player in our future illumination design conferences.

Beyond the special interest in freeform technology, it was clear that LED technology continues to be a very exciting and growing area of illumination optics. Clearly, as illumination optics has become a very important focus area for the optical community, LED technology has developed as the focal area for illumination optics sources. Two sessions on LED coupling, chaired by Julius Muschaweck of OSRAM GmbH, drew much international attention. No doubt LED's and their peripheral technologies will draw interest and R\&D resources long into the future.

A "Laser and Projection" session was highlighted by subjects including anamorphic illumination, near-IR illumination, speckle and mask alignment. Although, as compared with freeforms and LED's, these are more traditional optical subject areas, activities in these areas produce results of ongoing interest and continue to gather significant audiences. 
The session on "Optical Modeling," may also seem to many as a traditional subject area, but much of the advance today in optical illumination modeling deals with LED modeling and design analysis. As such, optical illumination modeling commands a growing interest and audience. We anticipate ongoing and interesting developments in optical illumination modeling to be presented in future conferences.

Our poster session included subjects on methods for color mixing, illumination evaluation, optical fiber light extraction, lighting quality for aluminum and prismatic light guides and an ultra-slim collimator. As always, we appreciate these poster papers which add an extra dimension to our conferences and allow an enhanced networking opportunity.

The R\&D presented in Illumination Optics II gives an understanding of fast moving developments affecting our daily lives. It appears obvious that Freeform surfaces is opening a wide spectrum of research in the lllumination Optics field as well as other areas of Optical design. We look forward to meeting you all again at our next SPIE, European "Optical Systems Design" conference.

Tina E. Kidger Stuart David 